\title{
Correction to: Clinical and histopathological analyses of VEGF receptors peptide vaccine in patients with primary glioblastoma - a case series
}

Ryota Tamura ${ }^{1}$, Yukina Morimoto ${ }^{1}$, Kenzo Kosugi ${ }^{1}$, Mizuto Sato ${ }^{1}$, Yumiko Oishi ${ }^{1}$, Ryo Ueda ${ }^{1}$, Ryogo Kikuchi ${ }^{2}$, Hideaki Nagashima', Tetsuro Hikichi', Shinobu Noji ${ }^{3}$, Yutaka Kawakami ${ }^{3}$, Hikaru Sasaki ${ }^{1}$, Kazunari Yoshida ${ }^{1}$ and Masahiro Toda ${ }^{1 *}$

\section{Correction to: BMC Cancer (2020) 20:196} https://doi.org/10.1186/s12885-020-6589-x

Following publication of the original article [1], the authors reported an error in the author group.

It was reported that Tetsuro Hikichi was missing and the corrected author group is as follows:

Ryota Tamura ${ }^{1}$, Yukina Morimoto ${ }^{1}$, Kenzo Kosugi ${ }^{1}$, Mizuto Sato ${ }^{1}$, Yumiko Oishi ${ }^{1}$, Ryo Ueda ${ }^{1}$, Ryogo Kikuchi $^{2}$, Hideaki Nagashima ${ }^{1}$, Tetsuro Hikichi ${ }^{4}$, Shinobu Noji $^{3}$, Yutaka Kawakami ${ }^{3}$, Hikaru Sasaki ${ }^{1}$, Kazunari Yoshida ${ }^{1}$ and Masahiro Toda ${ }^{1 *}$

The competing interests statement has been updated to:

$\mathrm{TH}$ is an employee of OncoTherapy Science, Inc.

The original article [1] has been corrected.

\section{Author details}

'Department of Neurosurgery, Keio University School of Medicine, 35 Shinanomachi, Shinjuku-ku, Tokyo 160-8582, Japan. ${ }^{2}$ Department of Neurosurgery, Hiratsuka City Hospital, Hiratsuka, Kanagawa 254-0019, Japan. ${ }^{3}$ Division of Cellular Signaling Institute for Advanced Medical Research, Keio University School of Medicine, 35 Shinanomachi, Shinjuku-ku, Tokyo
160-8582, Japan. ${ }^{4}$ OncoTherapy Science, Inc., 3-2-1, Sakado, Takatsu-ku, Kawasaki City, Kanagawa 213-0012, Japan.

Published online: 14 April 2020

\section{Reference}

1. Tamura R, Morimoto Y, Kosugi K, et al. Clinical and histopathological analyses of VEGF receptors peptide vaccine in patients with primary glioblastoma - a case series. BMC Cancer. 2020;20:196 https://doi.org/10. 1186/s12885-020-6589-x.

The original article can be found online at https://doi.org/10.1186/s12885020-6589-x

* Correspondence: todam@keio.jp

'Department of Neurosurgery, Keio University School of Medicine, 35

Shinanomachi, Shinjuku-ku, Tokyo 160-8582, Japan

Full list of author information is available at the end of the article

C C The Author(s). 2020 Open Access This article is licensed under a Creative Commons Attribution 4.0 International License, which permits use, sharing, adaptation, distribution and reproduction in any medium or format, as long as you give appropriate credit to the original author(s) and the source, provide a link to the Creative Commons licence, and indicate if changes were made. The images or other third party material in this article are included in the article's Creative Commons licence, unless indicated otherwise in a credit line to the material. If material is not included in the article's Creative Commons licence and your intended use is not permitted by statutory regulation or exceeds the permitted use, you will need to obtain permission directly from the copyright holder. To view a copy of this licence, visit http://creativecommons.org/licenses/by/4.0/ The Creative Commons Public Domain Dedication waiver (http://creativecommons.org/publicdomain/zero/1.0/) applies to the data made available in this article, unless otherwise stated in a credit line to the data. 